\title{
Assessment of Water Needs in Ezinihitte Local Government Area of Imo State, Nigeria
}

\author{
Onuoha Titus Nnadozie ${ }^{1}$, Verla Andrew Wirnkor ${ }^{2 *}$ \\ ${ }^{1}$ Department of Urban and Regional Planning, Imo State University, Owerri \\ ${ }^{2}$ Group Research in Analytical Chemistry, Environment and Climate Change (GRACE\&CC), Department of \\ Chemistry, Imo State University, Owerri, Nigeria.
}

*Corresponding Author: Verla Andrew Wirnkor, Group Research in Analytical Chemistry, Environment and Climate Change (GRACE\&CC), Department of Chemistry, Imo State University, Owerri, Nigeria.

\begin{abstract}
The study is aimed at assessing the water needs of the people of Ezinihitte LGA. This was cropped from the problem that emanated from the observed Government efforts on water provision, which had remained grossly inadequate to cover the entire communities, the dearth of available water facilities and how the villagers trek to long distances in search of water. Major issues of discourse included the distribution of water to households and how their water needs are tackled. Three hypotheses were tested and the questionnaire survey method was employed. The multi-stage sampling technique was used, and the sample size was 416. Data from the questionnaire were collected, tabulated into frequency distribution table and analyzed by using regression, correlation and ANOVA techniques. While testing the hypothesis, it was found that the quantity of water supplied was insufficient in the study area. Data from different sources show high positive correlation coefficient of variables indicating significant relationships between the quantities of water currently consumed and that required to be consumed. The study was concluded by recommending the involvement of the federal, state and local governments and other interest groups as well as the benefitting communities in water projects.
\end{abstract}

Keywords: Water Consumption, community welfare, sanitation

\section{INTRODUCTION}

Nigeria and the international community respectively have continued to make efforts to address the water provision, supply and its needs to the nation. Water is a unique resource that has no substitute (Origbo 2010). Its quality and quantity vary in space and time. Without water, life and civilization cannot survive, as water is a major catalyst for economic and social development. It is a very significant component in the overall development of a nation (Botxin and Kellers, 2000).

The need to meet the dynamic water requirements of the population is a most crucial issue facing the international organizations, all tiers of government and some non-governmental organizations. This could be attributed to rural expansion, population increase and lifestyle changes. The International community has continued to make effort to resolve water issues, which included: the Millennium Development Goals declaration on the halving of number of people who are unable to reach or to afford safe drinking water by 2015 . The declaration also aims at discontinuing the unsustainable exploitation of water resources by developing water management strategies at the regional, national and local levels that provide both equitable access and adequate supplies (United Nation, 2002)

At the national level, the federal government of Nigeria in January 2000 launched its national policy on water supply and sanitation, to provide sufficient potable water and adequate sanitation to all Nigerians in an affordable and sustainable manner (Federal Government of Nigeria, 2000). At the local level, many state government and their local government authorities (L.G.As) have complemented efforts of the federal government by creating different agencies such as water boards and rural water development agencies to provide water for the masses. Notable efforts were also made by different interest groups and donor agencies like the UNICEF, USAID, the World Bank (United Nations, 2006), European Union Assisted Water and Sanitation Project, LEEMP and others.

Most rural communities access water for their domestic and other water usage from Rivers, Lakes, Streams, Storm water ponds, Rain water and in some cases Boreholes. Despite the availability of the natural and manmade sources of water, there is still higher need for water especially in the developing 
nations. There are enormous efforts by various agencies and the government to address the water problems of the people of Imo State at the Local Government and Community levels (Okereke 2000, Pat-Mbano, Okeoma, Alaka and Onuoha (2010)... However, these efforts have remained grossly inadequate to cover her entire communities. According to the Federal Ministry of Water Resources (2000), water supply coverage in rural areas of Nigeria is 10 percent. In spite of the low figures, the average per capita delivery to the rural population is 10 litres per capita per day as against the national minimum standard of 113 litres per capita per day (Nwosah, 2003). Then the need to assess water needs becomes paramount. This is noticeable in Ezinihitte Local Government Areas which is our case study. The study is therefore aimed at assessing the water needs of the people of EzinihitteMbaise Area. The objectives to achieve the aim of this paper include; to determine the main source of water supply in EzinihitteMbaise LGA, to ascertain the quantity of water consumed in Ezinihitte LGA, to determine the quantity of water used for various purposes in Ezinihitte LGA, to examine the problems and prospects associated with sources of water, water consumption and water needs in Ezinihitte LGA, and to suggest ways of improving water supply in the study area.

The study is geared bringing to lime light water as an indispensable utility that aid in the development of our rural communities. This is information which has not been considered in finding solutions to some households' problems. The study will help to access the availability of water sources and facilities in helping to realize the felt needs of the people of Ezinihitte Local Government Area and beyond. It could be seen as a platform for rural water development. The government at all levels, international organizations, CBOs and other interest groups are required to utilize this opportunity to positively affect the rural communities in water provision, distribution and its accessibility.

\section{Materials AND Methods}

The map of the Nigeria showing Imo State is shown below

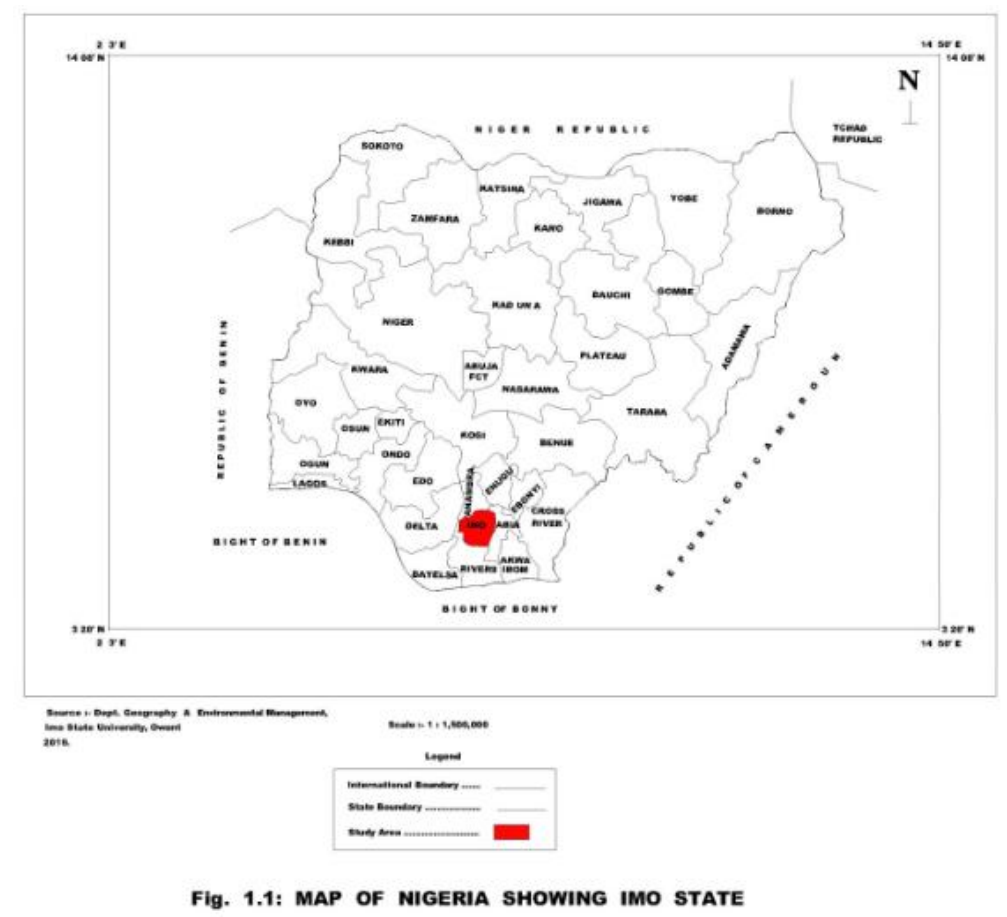

The survey research design was used for this study, because it is set to determine the influence of water availability and accessibility on the rural communities of Ezinihitte Local Government Area of Imo State. The survey was designed to ascertain information on demographic qualities (age, size, and occupation), sources of water, preference of sources, per capita consumption in relation to season, time to convey the water from the source, distance to sources, cost of water, mechanisms of transporting water, and associated socio-economic issues in Ezinihitte LGA. The populations of study were;

- The total number of sampled communities in Ezinihitte

- The total number of persons in Ezinihitte

- The total number of households in the sampled communities. 
Data was collected through primary and secondary sources. The heads of households constitute the study unit which was complemented with direct observation and focus group discussion. Secondary data sourced information from related or body of published works in academic journals, seminar papers, research reports, statistical reports, library and internet. The sample and sampling technique adopted in this study was as a result of critical consideration of some factors that could easily lead to the actualization of the target. The fourteen (14) communities in Ezinihitte constituted the sample frame. The multi-stage sampling technique was adopted. Four (4) communities were selected using the simple random sampling technique. The total of 416 heads of households formed the sample size with the aid of Taro Yamanes' formulawhich stated that

$n=\frac{N}{1+N(e)^{2}} \ldots \ldots \ldots \ldots \ldots$

Where $\mathrm{n}=$ the sample population, (416)

$\mathrm{N}=$ the study or finite population, $(\mathbf{1 6 5 , 5 9 3 )}$.

$\mathrm{e}=$ level of significance (or limit of tolerable error), (0.05)

$1=$ unity (a constant).

The systematic random sampling technique was used in the administration of the Questionnaire.In this technique, the whole buildings in the 4 communities were numbered from one to the last building. The total number of buildings formed the sampled frame at this stage. This was done community by community. In each of the community, the corresponding sets of questionnaire were administered, a set to one of each household of every community. In this case, one or two buildings were allowed during the administration of the questionnaire depending on the size of the community. If building one was sampled, the next 2 buildings would be left and the next building would be sampled. This was done in succession until the $416^{\text {th }}$ household was sampled. The analysis of the data collected in the course of the research was done using percentages, regression analysis techniques, different types of charts and mean. The instruments were used to present research data, determine and state the characteristics and trends of the sampled elements on the basis of which inferences/deductions were made.

\section{Results}

There are a number of sources of water supply in the study area. The major source of water in the study area is borehole.

Table1. Main source of water in Ezinihitte LGA

\begin{tabular}{|c|c|c|c|c|c|c|c|}
\hline \multicolumn{8}{|c|}{ MAIN SOURCES OF WATER } \\
\hline & & \multicolumn{4}{|c|}{ RESPONDENTS BY COMMUNITY } & \multirow[b]{2}{*}{ FREQUENCY } & \multirow[b]{2}{*}{ PER CENT } \\
\hline & & OBIZI & UDO & EZIUDO & OBOKWU & & \\
\hline \multirow{7}{*}{ SOURCES } & RIVER/STREAM & 13 & 61 & 6 & 12 & 92 & 22.1 \\
\hline & RAINWATER & 8 & 6 & 24 & 4 & 42 & 10.1 \\
\hline & BOREHOLES & 52 & 25 & 43 & 82 & 202 & 48.6 \\
\hline & VENDOR & 26 & 9 & 14 & 7 & 56 & 13.5 \\
\hline & WELLS & 1 & 3 & 5 & 0 & 8 & 1.9 \\
\hline & POND & 4 & 0 & 12 & 0 & 16 & 3.8 \\
\hline & TOTAL & 104 & 104 & 104 & 104 & 416 & 100 \\
\hline
\end{tabular}

Table2. The rating of water sources and supply in Ezinihitte LGA

\begin{tabular}{|c|c|c|c|c|c|c|}
\hline & \multicolumn{7}{|c|}{ Rating of Water Sources and Supply in the Study Area } \\
\cline { 2 - 8 } & $\begin{array}{c}\text { VERY } \\
\text { SOURCES }\end{array}$ & $\begin{array}{c}\text { INADEQUA } \\
\text { INE }\end{array}$ & $\begin{array}{c}\text { AVERA } \\
\text { GE }\end{array}$ & $\begin{array}{c}\text { ADEQUA } \\
\text { TE }\end{array}$ & $\begin{array}{c}\text { VERY } \\
\text { ADEQUATE }\end{array}$ & $\begin{array}{c}\text { TOTA } \\
\text { L }\end{array}$ \\
\hline $\begin{array}{c}\text { RIVER/STRE } \\
\text { AM }\end{array}$ & 154 & 142 & 86 & 27 & 7 & 416 \\
\hline RAINWATER & 112 & 299 & 5 & 0 & 0 & 416 \\
\hline BOREHOLES & 98 & 282 & 32 & 4 & 0 & 416 \\
\hline VENDOR & 215 & 188 & 11 & 2 & 0 & 416 \\
\hline WELLS & 401 & 5 & 0 & 0 & 0 & 416 \\
\hline POND & 404 & 11 & 1 & 0 & 0 & 416 \\
\hline AVERAGE & 231 & 155 & 23 & 6 & 1 & 416 \\
\hline
\end{tabular}


The quantities of water consumed and required to be consumed are shown below.

Table3. Quantity of water consumed per day in Ezinihitte LGA

\begin{tabular}{|c|c|c|c|c|c|c|c|c|c|}
\hline \multicolumn{9}{|c|}{ QUANTITY OF WATER CONSUMED IN EZINIHITTE LGA } & \multirow[b]{3}{*}{ PER CENT } \\
\hline \multirow{2}{*}{$\begin{array}{c}\text { QUANTITY OF } \\
\text { WATER } \\
\text { CONSUMED DAILY }\end{array}$} & \multicolumn{7}{|c|}{ NO OF HOUSEHOLDS BY SIZE } & \multirow[b]{2}{*}{ FREQUENCY } & \\
\hline & 1 & 2 & 3 & 4 & 5 & 6 & $6+$ & & \\
\hline 1 -20LITRES & 52 & 11 & 3 & 0 & 0 & 0 & 0 & 66 & 15.9 \\
\hline 21-40LITRES & 9 & 11 & 17 & 36 & 74 & 3 & 0 & 150 & 36.1 \\
\hline 41-60LITRES & 0 & 1 & 2 & 8 & 6 & 4 & 16 & 37 & 8.9 \\
\hline 61-80LITRES & 0 & 0 & 1 & 3 & 7 & 15 & 71 & 97 & 23.2 \\
\hline 81-100LITRES & 0 & 0 & 0 & 1 & 1 & 4 & 27 & 33 & 7.9 \\
\hline 101-120LITRES & 0 & 0 & 0 & 0 & 0 & 2 & 24 & 26 & 6.3 \\
\hline ABOVE 120 LITRES & 0 & 0 & 0 & 0 & 0 & 1 & 6 & 7 & 1.7 \\
\hline TOTAL & & & & & & & & 416 & 100 \\
\hline
\end{tabular}

Table4. Quantity of water required to be consume per day in Ezinihitte LGA

\begin{tabular}{|c|c|c|c|c|c|c|c|c|c|c|c|c|c|c|}
\hline \multirow{3}{*}{$\begin{array}{l}\text { DAILY QTY } \\
\text { OF WATER }\end{array}$} & \multicolumn{14}{|c|}{ NUMBER OF HOUSEHOLD BY SIZE } \\
\hline & \multicolumn{2}{|c|}{1} & \multicolumn{2}{|c|}{2} & \multicolumn{2}{|c|}{$\mathbf{3}$} & \multicolumn{2}{|c|}{4} & \multicolumn{2}{|c|}{5} & \multicolumn{2}{|c|}{6} & \multicolumn{2}{|c|}{$6+$} \\
\hline & $\mathbf{C}$ & $\mathbf{R}$ & $\mathbf{C}$ & $\mathbf{R}$ & C & $\mathbf{R}$ & C & $\mathbf{R}$ & $\mathbf{C}$ & $\mathbf{R}$ & C & $\mathbf{R}$ & $\mathbf{C}$ & $\mathbf{R}$ \\
\hline $1-20 \mathrm{~L}$ & $\begin{array}{c}52 \\
(85 \\
\%)\end{array}$ & $\begin{array}{l}12 \\
(20 \\
\%)\end{array}$ & $\begin{array}{l}11 \\
(48 \\
\%)\end{array}$ & 0 & $\begin{array}{c}3 \\
(13 \\
\%)\end{array}$ & 0 & 0 & 0 & 0 & 0 & 0 & 0 & 0 & 0 \\
\hline $21-40 \mathrm{~L}$ & $\begin{array}{c}9 \\
(15 \\
\%)\end{array}$ & $\begin{array}{l}41 \\
(67 \\
\%)\end{array}$ & $\begin{array}{l}11 \\
(48 \\
\%)\end{array}$ & $\begin{array}{c}7 \\
(30 \\
\%)\end{array}$ & $\begin{array}{l}17 \\
(74 \\
\%)\end{array}$ & $\begin{array}{c}3 \\
(13 \\
\%)\end{array}$ & $\begin{array}{l}36 \\
(75 \\
\%)\end{array}$ & 0 & $\begin{array}{c}74 \\
(84 \\
\%)\end{array}$ & 0 & $\begin{array}{c}3 \\
(10 \\
\%)\end{array}$ & 0 & 0 & 0 \\
\hline $41-60 \mathrm{~L}$ & 0 & $\begin{array}{c}8 \\
(13 \\
\%)\end{array}$ & $\begin{array}{l}1 \\
(4 \\
\%)\end{array}$ & $\begin{array}{l}11 \\
(48 \\
\%)\end{array}$ & $\begin{array}{l}2 \\
(9 \\
\%)\end{array}$ & $\begin{array}{c}9 \\
(39 \\
\%)\end{array}$ & $\begin{array}{c}8 \\
(17 \\
\%)\end{array}$ & $\begin{array}{c}9 \\
(19 \\
\%)\end{array}$ & $\begin{array}{l}6 \\
(7 \\
\%)\end{array}$ & 0 & $\begin{array}{c}4 \\
(14 \\
\%)\end{array}$ & 0 & $\begin{array}{l}16 \\
(11 \\
\%)\end{array}$ & 0 \\
\hline $61-80 \mathrm{~L}$ & 0 & 0 & 0 & $\begin{array}{c}5 \\
(22 \\
\%)\end{array}$ & $\begin{array}{c}1 \\
(4 \\
\%)\end{array}$ & $\begin{array}{c}9 \\
(39 \\
\%)\end{array}$ & $\begin{array}{c}3 \\
(6 \\
\%)\end{array}$ & 16 & $\begin{array}{l}7 \\
(8 \\
\%)\end{array}$ & $\begin{array}{c}3 \\
(3 \\
\%)\end{array}$ & $\begin{array}{c}15 \\
(52 \\
\%)\end{array}$ & 0 & $\begin{array}{l}71 \\
(49 \\
\%)\end{array}$ & 0 \\
\hline $81-100 \mathrm{~L}$ & 0 & 0 & 0 & 0 & 0 & $\begin{array}{c}2 \\
(9 \\
\%) \\
\end{array}$ & $\begin{array}{c}1 \\
(2 \\
\%)\end{array}$ & $\begin{array}{c}19 \\
(33 \\
\%)\end{array}$ & $\begin{array}{l}1 \\
(1 \\
\%)\end{array}$ & $\begin{array}{l}16 \\
(18 \\
\%)\end{array}$ & $\begin{array}{c}4 \\
(14 \\
\%)\end{array}$ & $\begin{array}{c}4 \\
(14 \\
\%)\end{array}$ & $\begin{array}{l}27 \\
(19 \\
\%)\end{array}$ & 0 \\
\hline $101-120 \mathrm{~L}$ & 0 & 0 & 0 & 0 & 0 & 0 & 0 & $\begin{array}{c}3 \\
(6 \\
\%)\end{array}$ & 0 & $\begin{array}{l}54 \\
(61 \\
\%)\end{array}$ & $\begin{array}{c}2 \\
(7 \\
\%)\end{array}$ & $\begin{array}{l}14 \\
(48 \\
\%)\end{array}$ & $\begin{array}{l}24 \\
(17 \\
\%)\end{array}$ & $\begin{array}{l}25 \\
(17 \\
\%)\end{array}$ \\
\hline$>120 \mathrm{~L}$ & 0 & 0 & 0 & 0 & 0 & 0 & 0 & $\begin{array}{c}1 \\
(2 \\
\%)\end{array}$ & 0 & $\begin{array}{c}15 \\
(17 \\
\%)\end{array}$ & $\begin{array}{c}1 \\
(3 \\
\%)\end{array}$ & $\begin{array}{l}11 \\
(38 \\
\%)\end{array}$ & $\begin{array}{l}6 \\
(4 \\
\%)\end{array}$ & $\begin{array}{l}119 \\
(83 \\
\%)\end{array}$ \\
\hline TOTAL/2 & & & & & & & & & & & & $\%$ & & \\
\hline $\begin{array}{l}\text { GRAND } \\
\text { TOTAL }\end{array}$ & & & & & & & & & & & & & & \\
\hline
\end{tabular}

Table5. The average quantity of water consumed / required to be consumed in Ezinihitte LGA.

\begin{tabular}{|c|c|c|}
\hline \multicolumn{2}{|c|}{ AVERAGE HOUSEHOLD WATER CONSUMPTION IN LITRES } \\
\hline $\begin{array}{c}\text { DAILY QTY OF WATER } \\
\text { CONSUMED }\end{array}$ & $\begin{array}{c}\text { QTY CONSUMED BY } \\
\text { HOUSEHOLD }\end{array}$ & $\begin{array}{c}\text { QTY REQUIRED BY } \\
\text { HOUSEHOLD }\end{array}$ \\
\hline $1-20$ & 660 & 120 \\
\hline $21-40$ & 4500 & 1530 \\
\hline $41-60$ & 1850 & 2310 \\
\hline $61-80$ & 6790 & 3690 \\
\hline $81-100$ & 2970 & 10560 \\
\hline $101-120$ & 2860 & 17520 \\
\hline ABOVE 120 & 840 & 25100 \\
\hline TOTAL & 19900 & 180 \\
\hline
\end{tabular}


Average Qty consumed 48\%, Average Qty required 60\%,

Differences in Quantity 25,100 - 19,900 =6,200 Litres

The actual water consumption and the required water consumption distribution in Ezinihitte LGA are presented below.

Table6. The actual water consumption distribution in Ezinihitte LGA.

\begin{tabular}{|c|c|c|c|c|c|c|c|}
\hline \multicolumn{8}{|c|}{ WATER CONSUMPTION DISTRIBUTION IN EZINIHITTE LGA } \\
\hline \multirow{2}{*}{\multicolumn{2}{|c|}{ (Water in litres) }} & \multicolumn{4}{|c|}{ COMMUNITIES } & \multirow[b]{2}{*}{$\begin{array}{c}\text { FREQUENC } \\
\mathrm{Y}\end{array}$} & \multirow[b]{2}{*}{$\begin{array}{c}\text { PER } \\
\text { CENT }\end{array}$} \\
\hline & & $\underline{\text { OBIZI }}$ & $\underline{\mathrm{UDO}}$ & $\frac{\text { EZIUD }}{\underline{\mathrm{O}}}$ & $\frac{\mathrm{OBOKW}}{\underline{\mathrm{U}}}$ & & \\
\hline \multirow{6}{*}{$\begin{array}{c}\text { WATE } \\
\underline{\mathrm{R}} \\
\underline{\text { USES }}\end{array}$} & DRINKING & 482 & 497 & 488 & 592 & 2059 & 10.35 \\
\hline & $\begin{array}{c}\text { WASHING/CLEANIN } \\
\text { G }\end{array}$ & 1548 & 1204 & 1962 & 1480 & 6194 & 31.13 \\
\hline & COOKING & 660 & 721 & 604 & 689 & 2674 & 13.43 \\
\hline & BATHING & 920 & 884 & 1327 & 891 & 4022 & 20.21 \\
\hline & OTHERS & 1237 & 983 & 1604 & 1127 & 4951 & 24.88 \\
\hline & TOTAL & $\begin{array}{c}4847 \\
(24.4 \% \\
)\end{array}$ & $\begin{array}{c}4289 \\
(21.6 \% \\
)\end{array}$ & $\begin{array}{l}5985 \\
(30 \%)\end{array}$ & $\begin{array}{l}4779 \\
(24 \%)\end{array}$ & 19900 & 100 \\
\hline
\end{tabular}

Sample Household $=416$

Table7. The required water consumption distribution in Ezinihitte LGA.

\begin{tabular}{|c|c|c|c|c|c|c|c|}
\hline \multicolumn{8}{|c|}{ REQUIRED WATER CONSUMPTION DISTRIBUTION IN EZINIHITTE LGA } \\
\hline \multirow{2}{*}{\multicolumn{2}{|c|}{ (Water in litres) }} & \multicolumn{4}{|c|}{ COMMUNITIES } & \multirow[b]{2}{*}{$\begin{array}{c}\text { FREQUENC } \\
\text { Y }\end{array}$} & \multirow[b]{2}{*}{$\begin{array}{c}\text { PER } \\
\text { CENT }\end{array}$} \\
\hline & & OBIZI & $\underline{\text { UDO }}$ & $\frac{\text { EZIUD }}{\underline{\mathrm{O}}}$ & $\frac{\mathrm{OBOK}}{\mathrm{WU}}$ & & \\
\hline \multirow{6}{*}{$\frac{\text { WATE }}{\underline{\text { R USES }}}$} & DRINKING & 566 & 547 & 599 & 654 & 2366 & 9.43 \\
\hline & $\begin{array}{c}\text { WASHING/CLEANIN } \\
\mathrm{G}\end{array}$ & 2298 & 1724 & 2910 & 2130 & 9062 & 36.1 \\
\hline & COOKING & 781 & 844 & 724 & 815 & 3164 & 12.61 \\
\hline & BATHING & 1321 & 1134 & 1747 & 1230 & 5432 & 21.64 \\
\hline & OTHERS & 1263 & 1014 & 1641 & 1158 & 5076 & 20.22 \\
\hline & TOTAL & $\begin{array}{c}6229 \\
(24.8 \%)\end{array}$ & $\begin{array}{c}5263 \\
(30 \%)\end{array}$ & $\begin{array}{c}7621 \\
(30.4 \%)\end{array}$ & $\begin{array}{c}5987 \\
(23.8 \%)\end{array}$ & 25100 & 100 \\
\hline
\end{tabular}

Sample Household $=416$

The tables showing problems and prospects are shown in tables 8 and 9 .

Table8. Major factors affecting water supply in Ezinihitte LGA

\begin{tabular}{|c|c|c|c|c|c|c|}
\hline \multicolumn{7}{|c|}{ MAJOR FACTORS AFFECTING WATER SUPPLY } \\
\hline & \multicolumn{7}{|c|}{ COMMUNITY } & & \\
\hline FACTOR & OBIZI & UDO & EZIUDO & OBOKWU & TOTAL & $\%$ DIST. \\
\hline INADEQUATE FINANCE & 11 & 24 & 21 & 15 & 71 & 17.1 \\
\hline POOR MGT/MAINTENANCE & 27 & 22 & 17 & 30 & 96 & 23.1 \\
\hline POPULATION INCREASE & 45 & 36 & 31 & 34 & 146 & 35.1 \\
\hline RIVER/STREAM DRYNESS & 8 & 2 & 0 & 14 & 24 & 5.8 \\
\hline RESTRICTION & 2 & 0 & 6 & 0 & 8 & 1.9 \\
\hline POOR WATER QUALITY & 4 & 3 & 8 & 3 & 18 & 4.3 \\
\hline LOCATION OF FACILITY & 7 & 17 & 21 & 8 & 53 & 12.7 \\
\hline TOTAL & & & & & 416 & 100 \\
\hline
\end{tabular}


Notwithstanding, the problems andprospects associated with sources of water, water consumption and water needs in Ezinihitte LGA are tabulated below.

Table9. Problems and Prospects

\begin{tabular}{|c|c|c|}
\hline S/N & PROBLEMS & PROSPECTS \\
\hline 1 & Lack of finance & $\begin{array}{c}\text { Proper budgetary allocation and freewill donations that will ensure } \\
\text { capital intensive projects and unique delivery of water projects as at } \\
\text { when due. }\end{array}$ \\
\hline 2 & $\begin{array}{c}\text { Poor maintenance and } \\
\text { management }\end{array}$ & $\begin{array}{c}\text { Standard water Agencies with proper orientation, grassroots } \\
\text { education and awareness drives with stated policies, laws and } \\
\text { regulations. }\end{array}$ \\
\hline 3 & Population increase & $\begin{array}{c}\text { Procurement and installation of more boreholes at strategic positions } \\
\text { which will ensure easy accessibility. }\end{array}$ \\
\hline 4 & River/Stream dryness & $\begin{array}{c}\text { A well dredged River/Stream that will help to boast the economy of } \\
\text { the communities in the study area and beyond. }\end{array}$ \\
\hline 5 & $\begin{array}{c}\text { Internal/External } \\
\text { Restrictions }\end{array}$ & $\begin{array}{c}\text { Provision of laws, policies and programmes that will be standard and } \\
\text { easy to adapt }\end{array}$ \\
\hline 6 & Poor location of facilities & Proper placement of facilities at central strategic positions \\
\hline 7 & $\begin{array}{c}\text { Community unfriendliness } \\
\text { expecution and maintenance. }\end{array}$ & \begin{tabular}{c} 
Absolute community participation in initiation, procurement, \\
\hline
\end{tabular} \\
\hline
\end{tabular}

\section{DISCUSSION}

It needs to be recalled that the aim of this study is to address the water needs of the people of Ezinihitte LGA in Imo state. The assessment is done by determining the main sources of water supply, establishing the water consumption in relation to World Health Organization standards, ascertaining the water needs, examining the problems and prospects associated with water sources, water consumption and water needs and suggesting ways of overcoming the identified shortcomings in Ezinihitte LGA. It is along this line that findings are made known.

\subsection{Main sources of water availability to residence}

The major sources of water in the 14 communities, of Ezinihitte LGA are surface water bodies (River and streams), rainwater harvesting, boreholes, water vendors and pond water. Few of the communities are endowed with the perennial surface water bodies. Boreholes which are the main source of water supply in the study area are mechanically operated with submersible pumps and it rated high $(48.6 \%)$ as the major water source in the study area. Boreholes are seen mostly in few rich individuals with a layout pipe outside their compound where they allow the ruralites to fetch water at a regulated price. The major limitation of this source is its high cost of installation.

The limitations of shallow well/ponds included - the high level of water pollution, associated with contamination from household and other environmental substances, - and the drying up of these ponds during the dry season. The water vending activities which is common in the study area has its limitation as poor road network and high cost of water. People are seen roaming around streets of the study area with jerry cans in search of water. It means therefore, that the available sources of water in the study area are insufficient for the consumers.

\subsection{Water consumption in relation to World Health Organization standard}

WHO (2018) described that in Nigeria the average per capita delivery to the urban population is only 32 litres per capita per day, for the small town 25 litres per capita per day, and 10 liter per capita per day for the rural area, as against the national minimum standard of 113 liters per day. This is in line with the findings of the study. The average water consumption per household per day in the study area is 48litres and (per person) per capita per day is 10 litres which is still below the National/WHO standard for water consumption. Tables 10 and 11 shows the differences between the quantity of water consumed and the quantity of water required to be consume. The result was also supported by the United Nations (2006) where the stated that the total availability per capita in Nigeria decreased from 2,514 cubic meters per year in 2000 to 2,250 cubic meters per year in 2009 . 
The rate of consumption in the study area is determined by the availability of the water, the accessibility and the income of the consumers. The variables were correlated and it shows high dependency rate (highly correlated). This also reflected in the hypothesis tested.

\subsection{Water needs in the study area}

The spread of water supply projects across the communities had been uneven, leaving large densely populated communities still unreached. The water needs of the people are not properly taken care of due to the absence of functioning water supply sites. From the report of the Project Implementation and Monitoring Report (2009), projects were executed in Ezinihitte under the Anambra/Imo River Basin Development Authority. They included Obizi and Amumara water Scheme. In Udo community, the two water projects executed are from NDDC and the Community and they are not functioning. LEEMP installed 2 in Obokwu community still functioning under the maintenance of the community. The central water scheme in Obizi is a history, likewise the one in Onicha, all in the study area. The majority of the water projects executed are privately owned. Public projects are 1, 2 or Non in each community.

The Federal Government of Nigeria (2004) noted that access to water supply in Nigeria has remained inadequate arising from years of neglect in the country. The researcher observed that majority of the households often resorted to private, informal arrangements such as water tankers, privately owned wells, hand - carried waters and hawkers of "pure water" of doubtful quality and high unit - cost rates for their water supply needs. Although the intervention of the Non - Governmental Organizations, Community Based Organization and other groups had relieved some communities, most other communities are still lacking sufficient water supply. It is even worst in some communities like Eziudo where pond water is still fully in existence. Most communities still travel longer distances to access greater quality of water as a result of absence of water projects within their location.

The lack of maintenance, functionality and sustainability of the water projects has been the noninvolvement of the benefiting communities in the planning and execution of projects in the communities. Some of the providers had their set rules not being community friendly. This results in dis-continuity of the projects after installation which in most cases (the projects) are too complex and beyond the technological know-how of the benefiting communities. By so doing, the projects were not effective and flow of services was unsustainable. From the foregoing, water supply has not been effective and sustainable due to the non-involvement of the benefitting communities in maintenance of the project facilities, identification of project options, operation of the project, using the water, locating the project, modes of consultation and information sharing and effective money outlay which were supposed to be tapped and applied in the project. The survey shows that the water needs of the study area has not been met and the various water uses has not been given favorable attention that will help alleviate the sufferings of the water consumers in Ezinihitte LGA. It was observed that the quantity of water needs amounted to 87,400 litres, while the quantity of water available was estimated to be 41,670 litres. The total of 45,730(52.3\%)litres becomes the deficiency. These shows that the quantity of water supplied (available) does not meet-up with the increasing need for water. As observed by the researcher, the respondents resort to self-help as a panacea to the water deficiency.

\subsection{Problems associated with sources of water, water consumption and water needs}

From the survey, some of the notable problems of water supply included - (a) Poor management of public boreholes which has lost considerable ground to private water borehole systems. Consumers now pay certain amount of money in exchange of water as against public project which were meant to be free or sold at a reduced cost. Obasi (2012) in her research noted such high price in AbohMbaise LGA. (b) Population increase in the study area posed danger in the quantity of water supplied. This manifest in water scarcity. This is in line with the hypothesis where the result shows that the quantity of water consumed has no significant relationship with the quantity of water required to consume. (c) River/Stream dryness: This is experienced sometimes during the dry season. Unfortunately, some parts of Onicha experienced water dryness due to the break - down of a hill by erosion. This affected a good number of streams that are along Onicha - Udo axis. This brings water supply shortage. 


\section{CONCLUSION}

The study has tried to assess the water needs of the communities in EzinihitteMbaise LGA. Results obtained have explicitly shown how most rural communities are being neglected in terms of the quantity of water supplied for the inhabitants. It has also shown how the rural population are not being given the opportunity to be involved in the decision - making, planning, implementation and operating projects that are been executed within their localities. The failure recorded in the study area was as a result of many factors which emanated from Human, Nature and other forces. Other forces included the inability of the authorities to carry - out their outlined policies and programmes which would have been beneficial to the communities especially in the area of water provisions. It will certainly cost less to constantly maintain the existing public water projects than abandoning them for the next regime to initiate another. Continuity has been the major problem.

The major limitations of the water supply in the study area has been the poor approach to community participation, shortfall of water sources and supply, poor government intervention, poor power supply, improper awareness and poor maintenance of facilities. Failure of the public water provision had posed greater dependency of the people on the alternative water source especially the private water borehole source. The result shows that much should be done in water provision to alleviate the problems of the communities in the study area. Recommendations were also made in this regard which included - the involvement of the federal, state, local Government and other interest groups in the provision of water projects. This should include continuing financial support from all area sectors (private individuals, NGOs, CBOs and the government). The benefitting communities should be fully involved in the planning, initiation, execution and management of the water supply projects to ensure continuity,

\section{ACKNOWLEDGMENTS}

I acknowledged the efforts of Paul Onuoha and my colleagues for their guidance, Prof.Pat-Mbano and Vivian Onuoha for their advice, Prof.Egbu, Dr. Ezirim and Prof. Uchegbu Smart for reviewing this paper, and all my facilitators and family members for supporting and sponsoring the preparation and conclusion of this paper. God bless you all.

\section{REFERENCES}

[1] African Development Fund (ADF). 2007. Rural water supply and sanitation sub-programmes in Yobe and Osun States of Nigeria-Appraisal report. Water and sanitation department (OWAS).

[2] Botkin, J. and Keller, E.A. 2000. Environmental science: Earth as a living plannet: New York: John Wiley and Sons Inc.

[3] Federal Government of Nigeria. 2004. National economic empowerment and development strategy (NEEDS), Abuja, Nigeria: National Planning Commission.

[4] Federal Government of Nigeria.2004. Water supply and sanitation.

[5] Federal Government of Nigeria.2004. Watershed and environmental management programme: A social assessment of Imo State, Nigeria. Kuzi LTD.

[6] Federal Ministry of Water Resources.2000. National policy on water supply and sanitation, Abuja Nigeria: Federal Ministry of Water Resources.

[7] National Population Commission.2006. Population census of Nigeria, 2006. Abuja: Federal Ministry of National Planning.

[8] Nwosah, G.C. 2003.Options for small town water supply and sanitation in Nigeria: $29^{\text {th }}$ WEDC international conference on towards the millennium development goals, Abuja, Nigeria $10^{\text {th }}-14^{\text {th }}$ August.

[9] Obasi2012.Rural water supply in AbohMbaise LGA. Unpublished Thesis of the Department of Urban and Regional Planning AbiaState .

[10] Okereke, P.A. 2000. The water problem in the old Imo Sate.The National Conference on Housing and Environmenal (CEENACON). Owerri: Imo State University.

[11] Okereke, P.A., Ebere, I.U. and U.E. Eze. 2000.Water supply management in Nigeria examples in some State.Owerri: Mcojee Publications.

[12] Origho T. 2010. Assessment of quality of rain water from different catchment roofs in rural areas of Ughelli North LGA of Delta State. Journal of Rural Water Supply in Nigeria.CAPE Publishers.

[13] Pat-Mbano, E.C., Okeoma I.O., Alaka I.N. and T. N. Onuoha.2010.Potable water supply in Owerrimetropolis.International Journals of Development and Management Review.(INJODEMAR), $5: 1$.

[14] United Nations. 2002. Millennium Declaration, New York: UN Economic and Social Council. 
[15] United Nations.2003. Report of the G8 Summit on water supply and sanitation, habitat debate: Water and sanitation for cities 9:3.

[16] United Nations. 2006. World water development report. New York: United Nations, economic and social council.

[17] United Nations Children and Education Fund.2000. Strategies for strengthening public agencies and programs. San Francisco: Jossey-Bass.

[18] World Health Organization (WHO).2010. Water and sanitation update 2010. Switzerland: WHO Press.

Citation: Onuoha Titus Nnadozie, Verla Andrew Wirnkor., “Assessment of Water Needs in Ezinihitte Local Government Area of Imo State, Nigeria", International Journal of Advanced Research in Chemical Science, 7(8), pp. 16-24. DOI: https:// doi.org/10.20431/2349-0403.0708002

Copyright: () 2020 Authors, this is an open-access article distributed under the terms of the Creative Commons Attribution License, which permits unrestricted use, distribution, and reproduction in any medium, provided the original author and source are credited. 